\title{
Effect of Sodium Benzoate and Sodium Phenylacetate on Brain Serotonin Turnover in the Ornithine Transcarbamylase-Deficient Sparse- Fur Mouse
}

\author{
MARK L. BATSHAW, SUSAN L. HYMAN, JOSEPH T. COYLE, MICHAEL B. ROBINSON, \\ IJAZ A. QURESHI, E. DAVID MELLITS, AND SHIRLEY QUASKEY \\ Departments of Pediatrics, Neurology, and Psychiatry, and John F. Kennedy Institute, Johns Hopkins University \\ School of Medicine, Baltimore, Maryland 21205 [M.L.B., S.L.H., M.B.R., E.D.M., S.Q.] and Department of \\ Pediatrics, University of Montreal, Hopital Ste. Justine, Montreal, Quebec, Canada [I.A.Q.]
}

\begin{abstract}
Herein we examine the effects of sodium benzoate and sodium phenylacetate on feeding and central serotonin turnover in a child with citrullinemia and in an animal model of congenital hyperammonemia, the ornithine transcarbamylase-deficient sparse-fur (spf/y) mouse. In the child, when the benzoate/phenylacetate dosage was increased from 200 to $375 \mathrm{mg} / \mathrm{kg} / \mathrm{day}$ each, feeding decreased. There was an accumulation of benzoate and phenylacetate in blood and cerebrospinal fluid as well as an increased concentration of 5-hydroxyindoleacetic acid, a neurochemical marker for serotonin turnover, in cerebrospinal fluid. In the mouse, sodium benzoate had a biphasic effect on both plasma ammonium levels and brain serotonin turnover. Two percent oral benzoate was associated with an increase in ammonium level, while a $3 \%$ dose led to a decrease in ammonium. There was a similar effect on serotonin turnover noted in both the hyperammonemic $s p f / y$ and control $C D-1 / y$ mice. Sodium phenylacetate did not have a consistent effect on serotonin turnover. The mechanism by which benzoate increases brain serotonin turnover appears to involve competition with tryptophan for albumin binding sites. This results in increased free tryptophan in serum and brain. We speculate that some of the clinical symptoms of benzoate intoxication may be a consequence of altered serotonin turnover in the brain. We suggest that drug levels be monitored during therapy. (Pediatr Res 23: 368-374, 1988)
\end{abstract}

\section{Abbreviations}

Trp, tryptophan

HIAA, 5-hydroxyindoleacetic acid

HPLC, high performance liquid chromatography

NE, norepinephrine

5-HT, serotonin

ANOVA, analysis of variance

GABA, $\gamma$-aminobutyric acid

CoA, coenzyme A

Sodium benzoate and sodium phenylacetate have proven effective in stimulating alternative pathways for waste nitrogen

Received June 26, 1987; accepted December 9, 1987

Correspondence Mark L. Batshaw, M.D., John F. Kennedy Institute, 707 N. Broadway, Baltimore, MD 21205.

Supported by USPHS Grant RO1-HD 10981 and MRRC Grant MA-9124. excretion in children with inborn errors of urea synthesis (1). This has resulted in prolonged survival. However, both intravenous drugs used to treat acute hyperammonemia and inadvertent oral overdoses have been associated with clinical toxicity including anorexia, irritability, lethargy, and coma $(1,2)$. Symptoms of intoxication in part simulate those of hyperammonemia.

The mechanism of these behavioral alterations is unclear. Bachmann et al. (3) reported increased brain uptake of Trp, the precursor of serotonin, in rats injected with $1 \mathrm{mmol} / \mathrm{kg}$ of sodium benzoate. Increased brain uptake of Trp and increased brain serotonin turnover have also been reported in experimentally induced and naturally occurring hyperammonemia (4-7). These findings, together with data showing an association of anorexia with increased serotonin turnover in children with urea cycle disorders (8), suggest that benzoate intoxication may involve altered serotonin turnover.

In studying the effect of benzoate and phenylacetate on serotonin turnover, we initially present a case report of a child with citrullinemia who developed toxic symptoms during high dose therapy and was found to have increased levels of the metabolite of serotonin, HIAA, in cerebrospinal fluid. We then examine in more detail the interaction of hyperammonemia and benzoate/ phenylacetate treatment on brain serotonin turnover in the chronically hyperammonemic ornithine transcarbamylase deficient sparse-fur $(s p f / y)$ mouse.

\section{METHODS}

Biochemical methods. Plasma ammonium was measured by a microfluorometric adaptation of a glutamate dehydrogenase method as previously described (4). Whole blood and plasma (sodium heparin) were obtained by cardiac puncture under ether anesthesia using a 25 -gauge needle. The mortality rate was $<10 \%$ with this procedure. The blood was immediately placed on ice, and ammonium levels assayed on $50 \mu \mathrm{l}$ plasma within $30 \mathrm{~min}$. An aliquot of plasma was precipitated with $5 \%$ sulfosalicylic acid and stored at $-4^{\circ} \mathrm{C}$ for subsequent analyses of amino acids by automated ion exchange column chromatography using a Beckman 6300 high pressure amino acid analyzer.

As heparin has been shown to decrease tryptophan binding to albumin, serum was used for tryptophan measurement (9). Free and bound tryptophan were immediately separated by ultrafiltration (Amicon Centrifree ultrafilter) using fixed angle rotor centrifugation at room temperature for $20 \mathrm{~min}$ at $2000 \times \mathrm{g}$. Total Trp concentrations in serum and free Trp in ultrafiltrates were measured immediately by an adaptation of an HPLC isocratic method with fluorometric detection as previously de- 
scribed $(4,10)$. Using this approach, there was no difference in free Trp levels between paired samples measured with or without $\mathrm{pH}$ control.

Cerebrospinal fluid measurements from the child with citrullinemia were obtained at $0700 \mathrm{~h}$ because of diurnal variation. The measures were taken at a 1 -month interval. On both occasions the child was receiving gastrostomy tube feedings by continuous infusion that stopped at $0200-0300 \mathrm{~h}$ and contained his total daily dose of benzoate and phenylacetate. During this time, he was also offered three meals a day using behavior management techniques as previously described (8).

In the mice, cortex was dissected by the method of Glowinski and Iverson (11), and $30 \mathrm{mg}$, diluted 1:20, was homogenized in a $0.1 \mathrm{~N}$ sodium acetate buffer, $\mathrm{pH} 4.95$ for measurement of $\mathrm{NE}$, HIAA, 5-HT, benzoate, phenylacetate, and Trp. Biogenic amines in cerebrospinal fluid and brain were determined by an isocratic HPLC method with electrochemical detection (4). Benzoate, phenylacetate, and hippurate concentrations were measured by an isocratic HPLC method with UV detection at $245 \mathrm{~nm}$ (1). Cortex, $100 \mathrm{mg}$, diluted 1:2, was homogenized in the same buffer and precipitated with 5\% sulfosalicylic acid before amino acid analysis by column chromatography. Twenty-four-h urine specimens for measurement of hippurate were collected using a polycarbonate metabolic cage (Econo-Cage, AH Thomas Co.)

Animals studied. Sparse-fur (spf/y) male mice, hemizygous for $\mathrm{X}$-linked ornithine transcarbamylase deficiency, were bred from the original Oak Ridge stock (12). The $s p f / y$ animals were the produce of matings of homozygous affected ( $s p f / s p f)$ females with normal $(+/ y)$ males from a $C D-1$ background. All male progeny of these matings are affected with ornithine transcarbamylase deficiency. Liver of these $s p f / y$ animals were removed at the time of sacrifice and stored at $-80^{\circ} \mathrm{C}$ for later determination of ornithine transcarbamylase activity. Ornithine transcarbamylase activity, measured by the method of Ceriotti (13), ranged from $3.6-8.8 \mu \mathrm{mol}$ citrulline formed $/ \mathrm{h} / \mathrm{mg}$ protein in $s p f / y$ compared to our previously reported activity of 88-112 in $C D-1$ mice (14). All animals studied were adults; however, the $s p f / y$ males were older (aged 2-6 months) than the control $C D$ 1 mice (Charles River; 2 months old).

All mice were fed an essential amino acid diet (Rogers-Harper, US Biochemical) providing $16 \%$ protein. For the study of longterm high dose oral administration, sodium benzoate (N.F.; Ruger Chemical Co.) was added to this amino acid mixture and made into pellets containing $0.1,2$, or $3 \%$ sodium benzoate (w/ w). This resulted in mean sodium benzoate intakes of $0,1.3,1.7$, and $3.0 \mathrm{~g} / \mathrm{kg} /$ day $(0,9,12,21 \mathrm{mmol} / \mathrm{kg} /$ day $)$ in $s p f / y$ mice. Serum sodium remained between $148-150 \mathrm{mEq} / \mathrm{liter}$ in all groups. Both $s p f / y$ and $C D-1 / y$ animals were divided into groups of five animals in each of the four treatment conditions $(0,1,2$, $3 \%$ benzoate). Two groups of $C D-1 / y$ mice were used, one was pair-fed with the matched $s p f / y$ mouse so that both groups ingested the same amount of benzoate; the other group was permitted to feed ad libitum in order to measure the effect of benzoate on food intake and weight. The biochemical studies were all performed on the pair-fed animals. All animals had a baseline period of 7 days receiving the amino acid diet, followed by a 5-day period receiving the amino acid diet plus the assigned dose of benzoate. Weights and food intake were measured daily during the study period.

To study the effects of bolus treatment used to treat acute hyperammonemic crises, sodium benzoate or sodium phenylacetate (Kendall-McGaw Pharmaceutical Co.) was injected intraperitoneally at doses of 1 or $5 \mathrm{mmol} / \mathrm{kg}$. Animals injected with equimolar amounts of sodium acetate (Sigma Chemical Co.) were used as controls. Before injection, the animals were maintained on the amino acid diet for 7 days. The test compound was mixed with sterile water to give a final concentration of 100 $\mathrm{mM}$ for the $1 \mathrm{mmol} / \mathrm{kg}$ injections or $500 \mathrm{mM}$ for the $5 \mathrm{mmol} /$ $\mathrm{kg}$ injections. The animals were killed without anesthesia by decapitation $1 \mathrm{~h}$ after injection.
Statistical analysis. For the study of oral benzoate administration, there were four equally graduated benzoate dose groups $(0$, $1,2,3 \%$ ) within each type of experimental mouse, $s p f / y$ and $C D$ $1 / y$. An ANOVA with orthogonal contrasts was performed for the parameters measured in blood, urine, and brain of the eight study groups ( $n=5 /$ group). This analysis tested, in addition to the differences between the two experimental animals, the linear and nonlinear benzoate dose trends with respect to polynomial order of fit within each animal group.

For the study of intraperitoneal injections, a similar ANOVA analytic approach was used. However, different orthogonal contrasts were applied. These contrasts considered $s p f / y$ versus $C D$ $1 / y$ animals, differences within each animal group, and differences within and between acetate, phenylacetate, and benzoate treatments. A Bonferoni multiple comparison analysis was used to determine within group differences between specific benzoate dosages (15). For amino acid studies, significance was noted only at the $p<0.01$ level because of the multiple comparisons of related compounds.

\section{RESULTS}

Case report. The patient is an 8-yr-old boy who was diagnosed as having citrullinemia during a 4-day episode of hyperammonemic coma beginning at 5 days of age. Peak ammonium level was $1550 \mu \mathrm{M}$ (normal $<50 \mu \mathrm{M}$ ). Plasma citrulline levels are chronically elevated, $>2000 \mu \mathrm{M}$ (normal 10-34 $\mu \mathrm{M}$ ). T'reatment consists of a nitrogen restricted diet $(0.8 \mathrm{~g} / \mathrm{kg} /$ day $)$ supplemented with sodium benzoate $200 \mathrm{mg} / \mathrm{kg} /$ day, sodium phenylacetate $200 \mathrm{mg} / \mathrm{kg} / \mathrm{day}$, and arginine free-base $700 \mathrm{mg} / \mathrm{kg} /$ day. He has not subsequently had episodes of hyperammonemic coma, although he occasionally has elevations of plasma ammonium levels, in the range of $100-250 \mu \mathrm{M}$, as a result of excessive protein intake or an intercurrent infection. These episodes are manifest as irritability, lethargy, and vomiting and have responded within $24 \mathrm{~h}$ to treatment with intravenous arginine, sodium benzoate, and sodium phenylacetate.

The child is severely mentally retarded (mental age $2 \mathrm{yr}$ ) and refuses to eat food. This led to the placement of a gastrostomy feeding tube at $4 \mathrm{yr}$ of age. He was recently admitted to the Kennedy Institute for behavioral management of his food refusal Plasma ammonium level was $70 \mu \mathrm{M}$. An initial cerebrospinal fluid was obtained to measure levels of HIAA because of our previous observation of elevated levels in anorectic children with urea cycle disorders (8). We noted his HIAA level to be normal, $0.17 \mu \mathrm{M}$ or $33 \mathrm{ng} / \mathrm{dl}$ (normal $0.11-0.23 \mu \mathrm{M}$ ). Once food refusal was behaviorally modified he began to eat spontaneously. It appeared therefore that he had food refusal rather than anorexia.

As a result of intermittent hyperammonemia during this hospitalization, we increased both his benzoate and phenylacetate dosage from 200 to $375 \mathrm{mg} / \mathrm{kg} /$ day, while retaining unchanged his protein $(0.8 \mathrm{~g} / \mathrm{kg} /$ day $)$, caloric $(1000-1300 \mathrm{cal})$, and arginine $(700 \mathrm{mg} / \mathrm{kg} /$ day $)$ intake. Three days after this increase, he developed symptoms of anorexia, irritability, and lethargy that simulated hyperammonemia. However, his ammonium level was 18 $\mu \mathrm{M}$. Plasma levels of benzoate and phenylacetate showed a 3- to 4-fold increase comparing doses of 375 to $200 \mathrm{mg} / \mathrm{kg} /$ day (Table 1). Free Trp in serum also increased at the high dose benzoate and phenylacetate. We obtained repeat cerebrospinal fluid levels of HIAA, benzoate, and phenylacetate and found them all to be markedly increased compared to the initial cerebrospinal fluid on the lower benzoate/phenylacetate dosage. The clinical symptoms abated within 2 days of decreasing the dosage of benzoate and phenylacetate.

This observation suggested that clinical benzoate/phenylacetate intoxication may be associated with increased serotonin turnover, manifest as increased levels of HIAA in cerebrospinal fluid. This was studied further in an animal model of hyperammonemia, the $s p f / y$ mouse.

Animal studies. Effects of Oral Benzoate. We found that the 
ornithine transcarbamylase-deficient $s p f / y$ mice had plasma ammonium levels that were approximately twice those found in unaffected $C D-1 / y$ mice (Table 2). Sodium benzoate treatment (1-3\% added to the feeds) resulted in an increase in ammonium levels at the $2 \%$ dosage and a decrease at the $3 \%$ dosage in both $s p f / y$ and $C D-1 / y$ mice. This biphasic (nonlinear) treatment effect reached statistical significance, $p<0.05$, in the $s p f / y$ mice.

In the pair-fed $s p f / y$ and $C D-1 / y$ mice, oral benzoate treatment resulted in significant increases in plasma benzoate and hippurate levels, and in urinary hippurate excretion. In the spf/ $y$ mice, plasma benzoate and hippurate levels and urinary hippurate excretion were linearly related to benzoate dose, $p<$ 0.001 . In the $C D-1 / y$ mice, a linear correlation $(p<0.001)$ was only demonstrated for urinary hippurate excretion. Benzoate and hippurate appeared to accumulate in plasma more in $s p f / y$ than in $C D-1 / y$ mice $(p<0.05)$. Between $20-29 \%$ of ingested benzoate was excreted as hippurate in urine over $24 \mathrm{~h}$.

Table 3 lists levels of NE, HIAA, 5-HT, and Trp in cortex of $s p f / y$ and $C D-1 / y$ mice under the various oral benzoate intakes. $s p f / y$ mice had significantly higher levels of HIAA $(p<0.001)$, $5-\mathrm{HT}$, and $\operatorname{Trp}(p<0.005)$ than did $C D-1 / y$ mice. There was no difference between $s p f / y$ and $C D-1 / y$ mice in levels of NE. Benzoate treatment had a significant effect on HIAA and Trp ( $p$ $<0.001)$ in $s p f / y$ mice. The effect of benzoate on HIAA and Trp fit best a biphasic (nonlinear) relationship $(p<0.001)$. There was a significant increase in these levels in animals receiving $1 \%$ benzoate and a significant decrease in animals receiving 3\% benzoate. There was no benzoate effect on levels of NE. In $C D$ -
$1 / y$ mice, there was a similar, but less significant nonlinear effect of benzoate intake on HIAA levels $(p<0.05)$.

In the nonpair fed animals, under the various treatment conditions, $s p f / y$ mice ate less food per body weight and lost more weight than did $C D-1 / y$ mice $(p<0.001)$ ( (Table 4). In the $s p f / y$ mice, $2 \%$ benzoate intake (which was associated with a significant increase in ammonium levels) resulted in a significant weight loss and decreased food intake $(p<0.05)$. There was neither a significant change in ammonium levels nor in feeding or weight in $C D-1 / y$ mice.

Effect of intraperitoneal sodium benzoate and sodium phenylacetate. In a second experiment $s p f / y$ and $C D-1 / y$ mice received intraperitoneal injections of sodium benzoate or sodium phenylacetate. Plasma benzoate and hippurate levels were markedly elevated $1 \mathrm{~h}$ after injection of 1 or $5 \mathrm{mmol} / \mathrm{kg}$ sodium benzoate (Table 5). After the $1 \mathrm{mmol} / \mathrm{kg}$ dose, the benzoate level in brain, although detectable, was low. However, there was a large accumulation of benzoate in cortex after the $5 \mathrm{mmol} / \mathrm{kg}$ dose. Sodium phenylacetate resulted in an even greater accumulation of phenylacetate in plasma and cortex. There were no significant differences in levels comparing $s p f / y$ and $C D-l / y$ mice. Animals treated with sodium acetate, as a control, had undetectable levels of benzoate, hippurate, and phenylacetate in blood and cortex. There was no mortality associated with the injections.

Plasma ammonium levels obtained $1 \mathrm{~h}$ after injection of sodium acetate, sodium benzoate, and sodium phenylacetate were significantly higher in $s p f / y$ as compared to $C D-l / y$ mice $(p<0.001)$ (Table 6). Compared to acetate, neither intraperito-

Table 1. Effect of varying dosage of benzoate/phenylacetate on cerebrospinal fluid HIAA levels in 8-yr-old with citrullinemia

\begin{tabular}{|c|c|c|c|c|c|c|c|c|}
\hline & \multirow{2}{*}{$\begin{array}{c}\begin{array}{c}\text { Dosage } \\
(\mathrm{mg} / \mathrm{kg} / \text { day })\end{array} \\
\begin{array}{c}\text { Benzoate/ } \\
\text { phenylacetate }\end{array}\end{array}$} & \multicolumn{4}{|c|}{ Plasma levels $(\mu \mathrm{M})$} & \multicolumn{3}{|c|}{ Cerebrospinal fluid $(\mu \mathrm{M})$} \\
\hline & & Ammonium & Free Trp & Benzoate & Phenylacetate & Benzoate & Phenylacetate & HIAA \\
\hline & 200 & 70 & 3.7 & 0.6 & 0.3 & 0.1 & ND & 0.17 \\
\hline & 375 & 18 & 5.8 & 1.7 & 1.1 & 5.8 & 0.8 & 0.51 \\
\hline Normal range & 0 & $<50$ & $3-17(17)^{*}$ & $\mathrm{ND} \dagger$ & ND & ND & ND & $0.11-0.23(16)^{*}$ \\
\hline
\end{tabular}

* Reference.

$\dagger$ Not detectable.

Table 2. Effect of oral benzoate 0-3\% on ammonium and benzoate metabolism in pair-fed spf/y and CD-1/y mice [mean (n=5 each group)]

\begin{tabular}{|c|c|c|c|c|c|c|}
\hline Benzoate intake & $(\%)$ & $\begin{array}{c}\text { Plasma } \\
\text { ammonium } \\
(\mu \mathrm{M})\end{array}$ & $\begin{array}{c}\text { Benzoate } \\
\text { intake } \\
(\mu \mathrm{mol} / 24 \mathrm{~h})\end{array}$ & $\begin{array}{c}\text { Urinary } \\
\text { hippurate } \\
(\mu \mathrm{mol} / 24 \mathrm{~h})\end{array}$ & $\begin{array}{c}\text { Plasma } \\
\text { benzoate } \\
(\mu \mathrm{M})\end{array}$ & $\begin{array}{c}\text { Plasma } \\
\text { hippurate } \\
(\mu \mathrm{M})\end{array}$ \\
\hline \multirow[t]{2}{*}{$s p f / y$} & 0 & 275 & 0 & Trace & 4 & ND \\
\hline & 1 & 275 & 290 & 59 & 14 & 48 \\
\hline \multirow[t]{4}{*}{$C D-1 / y$} & 0 & 106 & 0 & Trace & ND & ND \\
\hline & 1 & 132 & 300 & 90 & 7 & 42 \\
\hline & 2 & 156 & 517 & 110 & 22 & 80 \\
\hline & 3 & 132 & 704 & 149 & 6 & 30 \\
\hline Overall SD* & & 73 & 147 & 57 & 22 & 64 \\
\hline ANOVA & & & & $p$ & & \\
\hline \multicolumn{7}{|l|}{ Individual contrasts } \\
\hline$s p f / y$ vs $C D$ & & $<0.001$ & & & $<0.05$ & $<0.05$ \\
\hline$s p f / y$ linear & & & $<0.001$ & $<0.001$ & $<0.001$ & $<0.001$ \\
\hline Nonlinear & & $<0.05$ & $<0.001$ & $<0.001$ & $<0.005$ & $<0.005$ \\
\hline$C D-1 / y$ linear & & & $<0.001$ & $<0.001$ & & \\
\hline Nonlinear & & & $<0.001$ & $<0.001$ & & \\
\hline
\end{tabular}

\footnotetext{
${ }^{*} \mathrm{SD}$ for error from ANOVA, $\mathrm{df}=32$.
} 
Table 3. Effect of oral benzoate (0-3\%) on cortical biogenic amines in pair-fed spf/y and CD-1/y mice [mean, pmol/mg tissue $(n=5$ each group)]

\begin{tabular}{|c|c|c|c|c|c|}
\hline & $\begin{array}{c}\text { Benzoate } \\
\text { intake } \\
(\%)\end{array}$ & $\mathrm{NE}$ & HIAA & $5-\mathrm{HT}$ & Trp \\
\hline \multirow{4}{*}{$s p f / y$} & 0 & 2.24 & 2.82 & 3.44 & 37.6 \\
\hline & 1 & 2.05 & 4.11 & 4.67 & 77.7 \\
\hline & 2 & 2.37 & 2.91 & 3.34 & 46.3 \\
\hline & 3 & 1.64 & 1.83 & 2.57 & 32.1 \\
\hline \multirow[t]{4}{*}{$C D-1 / y$} & 0 & 1.56 & 1.45 & 2.69 & 30.0 \\
\hline & 1 & 1.74 & 2.21 & 2.36 & 34.6 \\
\hline & 2 & 2.86 & 2.08 & 1.81 & 41.5 \\
\hline & 3 & 1.49 & 2.21 & 2.51 & 40.1 \\
\hline \multirow{2}{*}{\multicolumn{2}{|c|}{$\begin{array}{l}\text { Overall SD } \\
\text { ANOVA }\end{array}$}} & 0.96 & 0.53 & 1.20 & 10.2 \\
\hline & & & & $p$ & \\
\hline \multirow{2}{*}{\multicolumn{3}{|c|}{$\begin{array}{l}\text { Individual contrasts } \\
\text { spf/y vs } C D\end{array}$}} & & & \\
\hline & & & $<0.001$ & $<0.005$ & $<0.005$ \\
\hline \multicolumn{2}{|l|}{$s p f / y$ linear } & & $<0.001$ & & $<0.05$ \\
\hline \multicolumn{2}{|l|}{ Nonlinear } & & $<0.001$ & & $<0.001$ \\
\hline \multicolumn{6}{|l|}{$C D-1 / y$ linear } \\
\hline Nonlinear & & & $<0.05$ & & \\
\hline
\end{tabular}

Table 4. Effect of oral benzoate (0-3\%) on wt and feeding over 4

\begin{tabular}{|c|c|c|c|c|}
\hline & $\begin{array}{c}\text { Benzoate } \\
\text { intake } \\
(\%)\end{array}$ & $\mathrm{Wt}(\mathrm{g})$ & $\begin{array}{c}\text { Wt } \\
\text { change } \\
(\mathrm{g})\end{array}$ & $\begin{array}{l}\text { Daily food } \\
\text { intake }(g / \\
\text { wt) }\end{array}$ \\
\hline$s p f / y$ & $\begin{array}{l}0 \\
1 \\
2 \\
3\end{array}$ & $\begin{array}{l}35 \\
33 \\
40 \\
37\end{array}$ & $\begin{array}{l}-0.8 \\
-0.4 \\
-3.8 \\
-2.2\end{array}$ & $\begin{array}{l}0.12 \\
0.15 \\
0.08 \\
0.11\end{array}$ \\
\hline$C D-1 / y$ & $\begin{array}{l}0 \\
1 \\
2 \\
3\end{array}$ & $\begin{array}{l}29 \\
28 \\
28 \\
27\end{array}$ & $\begin{array}{l}0.4 \\
3.2 \\
0.8 \\
2.0\end{array}$ & $\begin{array}{l}0.14 \\
0.16 \\
0.16 \\
0.14\end{array}$ \\
\hline $\begin{array}{l}\text { Overall SD } \\
\text { ANOVA }\end{array}$ & & 3 & $\begin{array}{l}2.3 \\
p\end{array}$ & 0.03 \\
\hline $\begin{array}{l}\text { Individual contrasts } \\
\quad s p f / y C D\end{array}$ & & $<0.001$ & $<0.001$ & $<0.001$ \\
\hline $\begin{array}{l}t \text { tests } \\
s p f / y \text { benzoate } \\
2 \% \\
v s \text { benzoate } 0 \% \\
C D-1 / y \text { benzoate } \\
2 \% \\
v s \text { benzoate } 0 \%\end{array}$ & & $<0.05$ & $<0.05$ & $<0.05$ \\
\hline
\end{tabular}

neal benzoate nor phenylacetate at doses of 1 or $5 \mathrm{mmol} / \mathrm{kg}$ was associated with a difference in ammonium levels $1 \mathrm{~h}$ after injection compared to acetate in either $s p f / y$ or $C D-1 / y$ animals.

Pretreatment free Trp levels in serum were similar in $s p f / y$ and $C D-1 / y$ mice. Benzoate treatment resulted in a significant increase in free Trp levels compared to acetate in $C D-1 / y$ mice $(p$ $<0.005$ ) (Table 6). This was dose related. There was a similar trend $(p<0.09)$ in $s p f / y$ mice. Compared to sodium acetate, sodium phenylacetate had no effect on free Trp levels.

Table 6 also shows that the effects of intraperitoneal benzoate and phenylacetate on biogenic amine and tryptophan levels in $s p f / y$ cortex are similar to those observed in cerebrospinal fluid of our child with citrullinemia. All levels were significantly higher in $s p f / y$ as compared to $C D-1 / y$ mice. Benzoate administration was associated with a dose-related increase in HIAA $(p<0.001)$ and $\operatorname{Trp}(p<0.05)$ levels in $C D-1 / y$ mice. A similar but less significant effect was found in $s p f / y$ mice. Phenylacetate was not associated with changes in biogenic amines in $C D-1 / y$ mice. HIAA levels were modestly increased $(p<0.05)$ at the $5 \mathrm{mmol} /$ $\mathrm{kg}$ sodium phenylacetate dose compared to sodium acetate in spf/y mice.

Table 7 lists plasma amino acids after intraperitoneal benzoate. Only those amino acids that are relevant to the study are shown. There were no significant changes in the amino acids that are not shown. This convention is also used in Table 8. As expected in ornithine transcarbamylase deficiency, plasma glutamine levels were higher and citrulline levels lower in the $s p f / y$ as compared to the $C D-1 / y$ mice $(p<0.001)$. Additionally ornithine and lysine levels were lower in the $s p f / y$ animals. In the $C D-1 / y$ mice, benzoate treatment effects included lowering levels of serine, glycine, citrulline, lysine, and arginine $(p<0.01-p<0.001)$; ornithine was increased. In $s p f / y$ mice, differences were only noted at the $5 \mathrm{mmol} / \mathrm{kg}$ benzoate dosage on lowering glutamine, glycine, methionine, and alanine. As expected, injections of sodium acetate did not have any effect on amino acid levels. Plasma amino acids were not measured in the phenylacetatetreated group because, unlike man who acetylates phenylacetate with glutamine, mice metabolize phenylacetate as the glycine conjugate and the amino acid pattern might have been misleading (18).

Amino acids in cortex were measured under the $5 \mathrm{mmol} / \mathrm{kg}$ sodium benzoate and $5 \mathrm{mmol} / \mathrm{kg}$ sodium acetate conditions (Table 8). Glutamine levels were elevated in cortex of $s p f / y$ as compared to $C D-1 / y$ mice $(p<0.001)$. Benzoate infusion was not associated with a change in glycine or GABA. The lack of effect of benzoate on cortical glycine reflects the fact that glycine does not cross the blood-brain barrier (19), so that its formation occurs within the central nervous system and is not affected by peripheral conjugation of glycine with benzoate.

\section{DISCUSSION}

Sodium benzoate and sodium phenylacetate appear to be effective and generally well tolerated in the acute and chronic management of congenital hyperammonemia; reports of toxicity have been rare $(1,2)$. However, when toxicity does occur, the behavioral complex mimics hyperammonemia. This is illustrated by our child with citrullinemia who presented with anorexia and irritability. We found, in both this child and in the ornithine transcarbamylase-deficient sparse-fur mouse, that the anorexia and weight loss was associated with increased 5-HT turnover. This was manifest as increased levels of Trp, the precursor of 5HT, and of HIAA, its principal metabolite in cerebrospinal fluid of our patient and in cortex of the $s p f / y$ mouse.

This finding is compatible with the known role of 5-HT in appetite suppression (20), and suggests that the anorexia associated with benzoate overdose in children may be a consequence of increased central 5-HT turnover. This phenomenon was found both in the hyperammonemic $s p f / y$ mice and in the normoammonemic $C D-1 / y$ mice. In our patient this effect occurred at a benzoate dose less than twice that recommended for long-term therapy, 375 versus $250 \mathrm{mg} / \mathrm{kg} /$ day (1). In the mice the effect was consistently seen at doses of benzoate more than 3-fold higher than the recommended dose.

The mechanism of the increased serotonin turnover seems to involve competition of benzoate with Trp for albumin binding sites, resulting in increased free Trp levels in blood. We found that free Trp levels in serum obtained $1 \mathrm{~h}$ after intraperitoneal injections of benzoate, $5 \mathrm{mmol} / \mathrm{kg}$, were increased in both $s p f / y$ and $C D-1 / y$ mice. Similar results were reported by Iwata $e t$ al. (21) who studied the effects of various drugs, including sodium benzoate, on free serum Trp levels in rats. Unlike other amino acids, Trp exists in both bound and free forms in blood (22). 
Table 5. Effect of intraperitoneal benzoate or phenylacetate on metabolite levels obtained 1 h later in plasma and cortex [mean (range)]

\begin{tabular}{|c|c|c|c|c|c|}
\hline & $\begin{array}{c}\text { Plasma } \\
\text { hippurate } \\
(\mu \mathrm{M})\end{array}$ & $\begin{array}{l}\text { Plasma benzoate } \\
\qquad(\mu \mathrm{M})\end{array}$ & $\begin{array}{l}\text { Cortical benzoate } \\
\text { (pmol/mg tissue) }\end{array}$ & $\begin{array}{c}\text { Plasma } \\
\text { phenylacetate } \\
(\mu \mathrm{M})\end{array}$ & $\begin{array}{c}\text { Cortical } \\
\text { phenylacetate } \\
\text { (pmol/mg tissue) }\end{array}$ \\
\hline \multicolumn{6}{|l|}{$s p f / y^{*}$} \\
\hline Acetate $(1 \mathrm{mmol} / \mathrm{kg})$ & $\mathrm{ND}+$ & ND & ND & ND & ND \\
\hline Acetate $(5 \mathrm{mmol} / \mathrm{kg})$ & ND & ND & ND & ND & ND \\
\hline Benzoate $(1 \mathrm{mmol} / \mathrm{kg})$ & $35(0-163)$ & $85(0-380)$ & $29(0-143)$ & ND & ND \\
\hline Benzoate $(5 \mathrm{mmol} / \mathrm{kg})$ & $341(224-504)$ & $6362(4473-8245)$ & $2239(1849-2892)$ & ND & ND \\
\hline Phenylacetate $(5 \mathrm{mmol} / \mathrm{kg})$ & ND & ND & ND & $9367(7796-11072)$ & $3832(3162-4080)$ \\
\hline \multicolumn{6}{|l|}{$C D-1 / y$} \\
\hline Acetate $(1 \mathrm{mmol} / \mathrm{kg})$ & ND & ND & ND & ND & ND \\
\hline Acetate $(5 \mathrm{mmol} / \mathrm{kg})$ & ND & ND & ND & ND & ND \\
\hline Benzoate $(1 \mathrm{mmol} / \mathrm{kg})$ & $74(7-298)$ & $30(0-112)$ & ND & ND & ND \\
\hline Benzoate $(5 \mathrm{mmol} / \mathrm{kg})$ & $253(140-472)$ & $5627(5070-6303)$ & $2581(2164-2931)$ & ND & ND \\
\hline
\end{tabular}

* No significant differences between $s p f / y$ and $C D-1 / y$.

$\dagger$ Not detectable.

Table 6. Effect $1 \mathrm{~h}$ after intraperitoneal benzoate or phenylacetate on plasma ammonium, Trp, and cortical biogenic amines [mean $(n=5$ each group $)]$

\begin{tabular}{|c|c|c|c|c|c|c|c|c|}
\hline & \multicolumn{4}{|c|}{ Plasma levels $(\mu \mathrm{M})$} & \multicolumn{4}{|c|}{ Levels in cortex (pmol/mg tissue) } \\
\hline & \multirow[b]{2}{*}{ NH4 } & \multicolumn{2}{|c|}{ Free-Trp } & \multirow{2}{*}{$\begin{array}{l}\text { Change in } \\
\text { free-Trp }\end{array}$} & \multirow[b]{2}{*}{ NE } & \multirow[b]{2}{*}{ HIAA } & \multirow[b]{2}{*}{ HT } & \multirow[b]{2}{*}{$\operatorname{Trp}$} \\
\hline & & Pre & Post & & & & & \\
\hline \multicolumn{9}{|l|}{$s p f / y$} \\
\hline Acetate $(1 \mathrm{mmol} / \mathrm{kg})$ & 171 & 15.3 & 12.5 & -2.9 & 1.59 & 2.62 & 2.75 & 38.8 \\
\hline Acetate $(5 \mathrm{mmol} / \mathrm{kg})$ & 200 & 15.0 & 15.9 & 0.9 & 1.70 & 2.09 & 3.03 & 37.6 \\
\hline Benzoate $(1 \mathrm{mmol} / \mathrm{kg})$ & 206 & 12.7 & 14.4 & 1.7 & 1.85 & 2.51 & 3.15 & 30.1 \\
\hline Benzoate $(5 \mathrm{mmol} / \mathrm{kg})$ & 192 & 12.0 & 16.1 & 4.1 & 1.68 & 3.96 & 2.78 & 57.3 \\
\hline Phenylacetate $(1 \mathrm{mmol} / \mathrm{kg})$ & 164 & 10.9 & 14.1 & 3.2 & 1.56 & 2.48 & 2.11 & 24.2 \\
\hline Phenylacetate $(5 \mathrm{mmol} / \mathrm{kg})$ & 198 & 13.1 & 14.2 & 1.1 & 1.47 & 4.03 & 2.24 & 30.7 \\
\hline \multicolumn{9}{|l|}{$C D-1 / y$} \\
\hline Acetate $(1 \mathrm{mmol} / \mathrm{kg})$ & 123 & 11.2 & 14.0 & 2.8 & 1.57 & 1.95 & 1.84 & 27.0 \\
\hline Acetate $(5 \mathrm{mmol} / \mathrm{kg})$ & 144 & 11.6 & 12.0 & 0.4 & 1.25 & 1.67 & 1.33 & 27.8 \\
\hline Benzoate $(1 \mathrm{mmol} / \mathrm{kg})$ & 119 & 11.9 & 14.1 & 2.2 & 1.31 & 2.58 & 1.98 & 28.5 \\
\hline Benzoate $(5 \mathrm{mmol} / \mathrm{kg})$ & 132 & 10.4 & 25.5 & 15.1 & 1.32 & 3.12 & 1.68 & 44.7 \\
\hline Phenylacetate $(1 \mathrm{mmol} / \mathrm{kg})$ & 156 & 14.2 & 15.9 & 1.8 & 1.55 & 2.23 & 2.01 & 17.5 \\
\hline Phenylacetate $(5 \mathrm{mmol} / \mathrm{kg})$ & 202 & 12.5 & 14.8 & 2.3 & 1.71 & 2.85 & 2.45 & 22.4 \\
\hline Overall SD & 55 & 3.1 & 37.3 & 5.0 & 0.41 & 0.90 & 0.80 & 11.2 \\
\hline ANOVA & & & & & & & & \\
\hline \multicolumn{9}{|l|}{ Individual contrasts } \\
\hline$s p f / y$ vs $C D-1$ & $<0.001$ & & & $<0.05$ & $<0.05$ & $<0.01$ & $<0.001$ & $<0.001$ \\
\hline spf/y benzoate $1-5$ & & & & & & $<0.001$ & & $<0.001$ \\
\hline spf/y $A C$ vs benzoate & & & & & & $<0.005$ & & \\
\hline$C D$ benzoate $1-5$ & & & $<0.001$ & $<0.001$ & & & & $<0.005$ \\
\hline$C D A C$ vs benzoate & & & $<0.001$ & $<0.005$ & & $<0.001$ & & $<0.05$ \\
\hline \multicolumn{9}{|c|}{ Multiple comparisons (Bonferroni) } \\
\hline$s p f / y$ AC5 vs PA5 & & & & & & $<0.05$ & & \\
\hline$C D A C 5$ vs PA5 & & & & & & & & \\
\hline
\end{tabular}

Free Trp represents approximately $15-25 \%$ of total Trp (23). There is evidence that it is the free Trp that is transported across the blood-brain barrier as substrate for 5-HT synthesis (17). As the activity of the 5-HT synthesizing enzyme, Trp hydroxylase, is not normally saturated in brain, increased brain Trp concentration would result in increased 5-HT synthesis and turnover (24).

In addition to benzoate competing for Trp binding sites, there may be a direct effect of benzoate on increasing brain Trp uptake. Bachmann et al. (3) found increased uptake of $\left[{ }^{14} \mathrm{C}\right]$ Trp after a benzoate bolus in both normoammonemic and hyperammonemic rats.

Unlike benzoate, injections of sodium phenylacetate did not result in an increase in free Trp levels in serum or serotonin turnover in cortex in either $s p f / y$ or $C D-1 / y$ mice. These results should be interpreted with some caution as phenylacetate is metabolized differently in rodents than in man (18).

In addition to studying the effect of benzoate on serotonin turnover in $s p f / y$ mice, we also approached the issue of whether benzoate can accentuate hyperammonemia. We noted that ben- 
BENZOATE, PHENYLACETATE, AND TRYPTOPHAN TURNOVER

Table 7. Effect of intraperitoneal benzoate on plasma amino acids obtained 1 h later [mean (SD) $\mu M$ ]

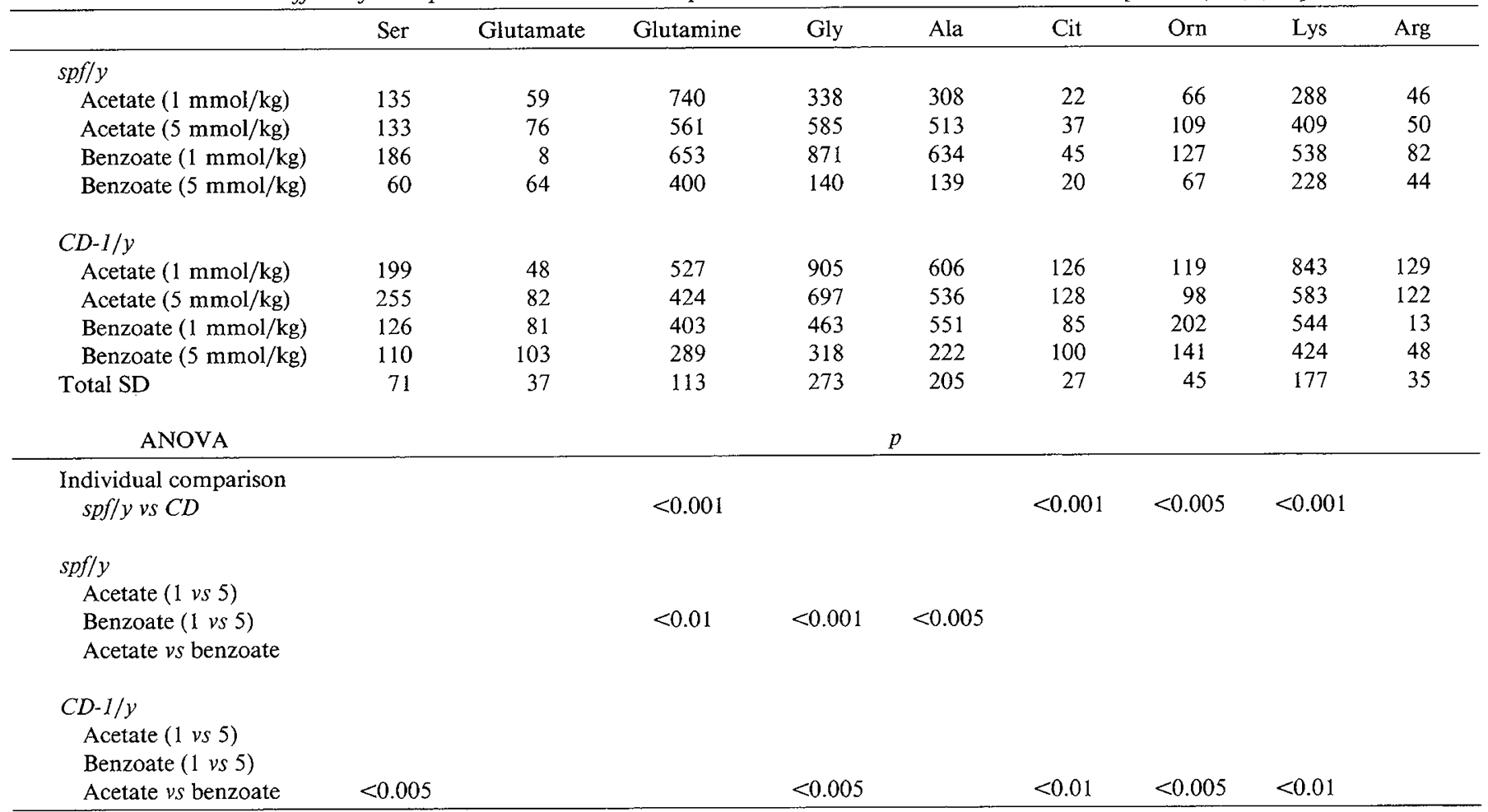

Table 8. Effect of intraperitoneal benzoate on brain amino acids [mean (nmol/mg tissue)]

\begin{tabular}{|c|c|c|c|c|c|c|c|c|c|c|}
\hline & Ser & Glutamate & Glutamine & Gly & Ala & Cit & GABA & Orn & Lys & Arg \\
\hline \multicolumn{11}{|l|}{$s p f / y$} \\
\hline Acetate $(5 \mathrm{mmol} / \mathrm{kg})$ & 368 & 4250 & 2835 & 333 & 371 & ND & 881 & 13 & 103 & 41 \\
\hline Benzoate $(5 \mathrm{mmol} / \mathrm{kg})$ & 353 & 3720 & 2979 & 415 & 329 & ND & 1039 & 18 & 122 & 42 \\
\hline \multicolumn{11}{|l|}{$C D-1 / y$} \\
\hline Acetate $(5 \mathrm{mmol} / \mathrm{kg})$ & 389 & 3679 & 1841 & 353 & 399 & ND & 926 & 16 & 111 & 45 \\
\hline Benzoate $(5 \mathrm{mmol} / \mathrm{kg})$ & 418 & 3900 & 1778 & 417 & 356 & ND & 1067 & 12 & 135 & 45 \\
\hline Overall SD & 64 & 523 & 515 & 50 & 56 & & 156 & 8 & 19 & 15 \\
\hline ANOVA & & & & & $p$ & & & & & \\
\hline \multicolumn{11}{|l|}{ Individual contrasts } \\
\hline$s p f / y v s C D$ & & & $<0.001$ & & & & & & & \\
\hline$s p f / y A C$ vs benzoate & & & & & & & & & & \\
\hline$C D A C$ vs benzoate & & & & & & & & & & \\
\hline
\end{tabular}

benzoate can accentuate hyperammonemia. We noted that benzoate had a nonlinear (biphasic) effect on plasma ammonium levels. Mice receiving $2 \%$ benzoate orally $(12 \mathrm{mmol} / \mathrm{kg} /$ day $)$ had higher ammonium levels than mice receiving both higher $(3 \%)$ and lower doses $(0$ or $1 \%)$. The lowest ammonium levels occurred at the $3 \%$ benzoate dose.

These findings support a paradoxical effect of benzoate on ammonium levels (25). At certain doses it may potentiate hyperammonemia, whereas at other doses it alleviates hyperammonemia. A possible explanation is that at a dose that leads to benzoate accumulation but little hippurate excretion, the effect of benzoate is to inhibit urea synthetic activity (26). There is evidence that the intermediate, benzoyl CoA, accumulates at high benzoate doses and that CoA-dependent processes are impaired as a result (27). One such process is the formation of $\mathrm{N}$ acetyl glutamate, the activator of the first enzyme in the urea cycle, carbamyl phosphate synthetase. However, this inhibitory effect is counterbalanced at a dose that results in a significant alternate pathway of waste nitrogen excretion as hippurate. Accentuation of hyperammonemia should not occur at the benzoate doses recommended for treatment of urea cycle disorders.
This biphasic effect of benzoate administration would be accentuated in mice, where excretion of hippurate is half than in man $(2,28)$. A lack of benefit of intravenous benzoate on ammonium levels in mice may be related to the short time $(1 \mathrm{~h})$ between injection and death. Benzoate levels in plasma of mice during oral therapy were comparable to those reported during long-term benzoate therapy in children with urea cycle disorders (1).

The biphasic effect of benzoate on ammonium levels was reflected in brain 5-HT turnover. Levels of Trp and HIAA in the cortex increased with $1-2 \%$ benzoate doses and decreased at $3 \%$ benzoate intake. It is also of note that the hyperammonemic spf/ $y$ mice consistently had higher 5-HT turnover than did the $C D$ $1 / y$ mice. These combined data suggest that hyperammonemia and benzoate increase 5-HT turnover in a synergistic fashion.

As a result of these studies, we suggest that the range of benzoate that may be given without clinical toxicity may be rather narrow. Further, some of the clinical findings of benzoate intoxication, including anorexia and lethargy, may be a consequence of increased 5-HT metabolism. It would seem appropriate to periodically measure benzoate levels in plasma, especially 
during high dose oral therapy or with intravenous bolus treatment of acute hyperammonemia in children with inborn errors of urea synthesis.

Acknowledgment. The authors acknowledge the editorial assistance of Susan Cascio and the technical support of Richard DeMurp and John Anegaw.

\section{REFERENCES}

1. Batshaw ML, Brusilow SW, Waber L, Blom W, Brubakk AM, Burton BK, Cann HM, Kerr D, Mamunes P, Matalon R, Meyerberg D, Schafer IA 1982 Treatment of inborn errors of urea synthesis; activation of alternative pathways of waste nitrogen synthesis and excretion. N Engl $\mathbf{J}$ Med 306:13871392

2. Brusilow SW, Danney M, Waber LJ, Batshaw M, Burton B, Levitsky L, Roth K, McKeethren C, Ward J 1984 Treatment of episodic hyperammonemia in children with inborn errors of urea synthesis. N Engl J Med 310:16301634

3. Bachmann C, Lüthi H, Gradwohl M, Colombo JP 1986 Brain uptake of tryptophan in urease-injected hyperammonemic rats after treatment with benzoate or hippurate. Biochem Med Metab Biol 36:214-219

4. Batshaw ML, Hyman SL, Mellits ED, Thomas GH, De Muro R, Coyle JT. 1986 Behavioral and neurotransmitter changes in the urease infused rat: a model of congenital hyperammonemia. Pediatr Res 20:1310-1315

5. Bachmann C, Colombo JP 1983 Increased tryptophan uptake into the brain in hyperammonemia. Life Sci 33:2417-2424

6. Bachmann C, Colombo JP 1984 Increase of tryptophan and 5-hydroxyindole acetic acid in the brain of ornithine carbamoyltransferase deficient sparse fur mice. Pediatr Res 18:372-375

7. Chaouloff F, Laude D, Mignot E, Kamoun P, Elghozi JL 1985 Tryptophan and serotonin turnover rate in the brain of genetically hyperammonemic mice. Neurochem Int 7:143-153

8. Hyman SL, Porter CA, Page TJ, Iwata BA, Kissel PR, Batshaw ML 1987 Behavioral management of feeding disturbances in urea cycle and organic acid disorders. J Pediatr 1 11:558-562

9. Bourgoin S, Faivre-Bauman A, Benda P, Glowinski J, Hamon M 1974 Plasma tryptophan and 5-HT metabolism in the CNS of the newborn rat. J Neurochem 123:319-327

10. Anderson GM, Young JG, Batter DK, Young SN, Cohen DJ, Shaywitz BA 1981 Determination of indoles and catechols in rat brain and pineal using liquid chromatography with fluorometric and amperometric detection. J Chromatogr 223:315-320

11. Glowinski J, Iverson LL 1966 Regional studies of catecholamines in the rat brain. I. The disposition of $[3 \mathrm{H}]$ dopamine and $[3 \mathrm{H}]$ DOPA in various regions of the brain. J Neurochem 13:655-669

12. DeMars R, LeVan SL, Trend BL, Russell LB 1976 Abnormal ornithine carbamoyltransferase in mice having the sparse-fur mutation. Proc Natl Acad Sci USA 73:1693-1697

13. Ceriotti G 1973 Optimal conditions for ornithine carbamyl transferase determination. A simple micromethod without deproteinization. Clin Chim Acta 47:97-105

14. Malo C, Qureshi IA, Letarte J 1986 Postnatal maturation of enterocytes in sparse-fur mutant mice. Am J Physiol 250:177-184

15. Feller N 1957 An Introduction to Probability Theory and its Applications, 2nd ed. Wiley \& Sons, New York

16. Hyman SL, Coyle JT, Parke JC, Porter C, Thomas GH, Jankel W. Batshaw ML 1986 Anorexia and altered serotonin metabolism in a patient with argininosuccinic aciduria. J Pediatr 108:705-709

17. Young SN, Samarthji L, Feldmuller F et al. 1976 Parallel variation of ventricular CSF tryptophan and free serum tryptophan in man. J Neurol Neurosurg Psychiat 39:61-65

18. James MO, Smith RL, Williams RT, Reidenberg M 1972 The conjugation of phenylacetic acid in man, sub-human primates and some non-primate species. Proc R Soc Lond [Biol] 182:25-35

19. Oldendorf WH 1971 Brain uptake of radiolabeled amino acids, amines and hexoses after arterial injection. Am J Physiol 221:1629-1639

20. Blundell JE 1984 Serotonin and appetite. Neuropharmacology 23:1537-1551

21. Iwata $H$, Okamoto $H$, Ko S 1975 Effects of various drugs on serum free and total tryptophan levels and brain tryptophan metabolism in rats. Jpn $\mathrm{J}$ Pharmacol 25:303-310

22. Mc Menamy RH, Oncley JL 1958 The specific binding of L-tryptophan to serum albumin. J Biol Chem 233:1436-1447

23. Hijikata Y, Hara K, Shiozaki Y, Murata K, Sameshima Y 1984 Determination of free tryptophan in plasma and its clinical applications. J Clin Chem Clin Biochem 22:291-299

24. Hamon M, Bourgoin F, Artaud F, El Mestikawy S 1981 The respective roles of tryptophan uptake and tryptophan hydroxylase in the regulation of serotonin synthesis in the central nervous system. J Physiol (Paris) 77:269 279

25. O'Connor JE, Costell M, Grisolia S 1987 The potentiation of ammonia toxicity by sodium benzoate is prevented by L-carnitine. Biochem Biophys Res Commun 145:817-24

26. Oyonagi K, Kuniya Y, Tsuchiyama A, Nakao N, Owada E, Sato J, Ito K 1987 Nonlinear elimination of benzoate in patients with congenital hyperammonemia. J Pediatr 110:634-636

27. Cyr DM, Maswoswe SM, Tremblay GC 1987 Inhibition of the urea cycle and de novo pyrimidine biosynthesis by sodium benzoate. J Inher Metab Dis 10(suppl 2):308-310

28. Qureshi I, Rouleau T, Letarte J, Ouellet R. 1986 Significance of transported glycine in the conjugation of sodium benzoate in spf mutant mice with ornithine transcarbamylase deficiency. Biochem Int 12:839-846 